\title{
LONG RUN AND SHORT RUN IMPACTS OF COVID-19 ON FINANCIAL MARKETS
}

DOI: 10.17261/Pressacademia.2020.1221

JBEF- V.9-ISS.2-2020(8)-p.155-170

\section{Gercek Ozparlak}

Beykent University, Vocational School, Department of International Trade, Istanbul, Turkey. gercekozparlak@beykent.edu.tr, ORCID ID: 0000-0002-8503-3199

\begin{tabular}{l}
\hline Date Received: April 16, $2020 \quad$ Date Accepted: June 6, 2020 \\
\hline To cite this document \\
Ozparlak, G., (2020). Long and short run impact of Covid-19 on financial markets. Journal of Business, Economics and Finance (JBEF), V.9(2), \\
p.155-170. \\
Permanent link to this document: $\underline{\text { http://doi.org/10.17261/Pressacademia.2020.1221 }}$ \\
Copyright: Published by PressAcademia and limited licensed re-use rights only. \\
\hline
\end{tabular}

\section{ABSTRACT}

Purpose- The purpose of this research is to contribute to the academic field by demonstrating long run and short run impact of Covid-19 virus on stock markets and CDS markets.

Methodology- In this paper, Johanse and Jeuselius (1990) Cointegration Test was used as the methodology to define the existence of thelongrun statistical relationship between Covid-19 data and economic variables of countries.

Findings- In the analysis, it was defined that there are at least two cointegration vectors in all countries. However, considering two countriesItaly and the USA, there is not significant long run relationship statistically. On the other hand, it can be noted that there is significant short run causality from CA to some variables. Moreover, there is no significant short run causality in France, Italy and the USA.

Conclusion- This article stated that there is the long term relationship between the total case of Covid-19 and China, France, Germany, the United Kingdom, Spain, Turkey. However, there is no long term relationship between the total cases of Covid-19 and France, Italy and the USA significantly. Furthermore, it can be said that there is significant short run causality from CA to some variables. However, there is no short run causality in France, Italy and the USA significantly. Finally, there is no long or short run causality in Italy and the USA.

Keywords: Covid-19, Corona, pandemic, stock markets, CDS, Johansen Cointegretion.

JEL Codes: E02, F00, G15

\section{INTRODUCTION}

Humanity has struggled with a pandemic that causes excessive number of deaths in every century for the long time. As can be seen in table 1, more than 200 million people died due to the Black Plague that emerged in the $14^{\text {th }}$ century, while $40-50$ million people died due to the Spanish flu that emerged in the 20th century. In addition, HIV / AIDS, killed 25-35 million people, still threatens humanity. Unfortunately, no vaccine has yet been developed for the disease.

Table 1: History of Pandemics

\begin{tabular}{|l|ccc|}
\hline \multicolumn{1}{|l}{ Name } & Time period & Century & Death toll \\
\hline Black Death & $1347-1351$ & 14 th & $200 \mathrm{M}$ \\
New World Smallpox Outbreak & 1520 - onwards & 16 th & $56 \mathrm{M}$ \\
Cholera Pandemics & $1817-1923$ & $19-20$ th & $1 \mathrm{M}+$ \\
Third Plague & 1885 & 19 th & $12 \mathrm{M}$ \\
Spanish Flu & $1918-1919$ & 20th & $40-50 \mathrm{M}$ \\
HIV/AIDS & 1981 -present & 20th & $25-35 \mathrm{M}$ \\
Covid-19 & 2019-Present & 21th & 287,670 \\
\hline
\end{tabular}

Today, we live in the 21st century and it is assumed that there have been many developments in the fields of health, medicine and technology. It was assumed that it would be impossible to have such a major outbreak as it was in the past. (Fernandes, 2020) indicated, when the Covid -19 is historically compared to SARS, the effects of the Covid-19 outbreak were underrated. 
However, the epidemic has first appeared in Wuhan, China then it spreads all over the world rapidly. Thus, it has become the biggest disaster in the world since The Second World War. At first, it was thought that the virus would be controlled in China, but the contagion speed of the virus was really fast. It has spread very quickly to almost every country in the world in twothree months. Therefore, World Health Organization (WHO) labelled Covid-19 Virus as pandemic on 11 February 2020. That means, a disease is prevalent more than one continent or over the world called as pandemic.

Figure 1: Total Confirmed Covid-19 Cases, Death, Recovery and Active Cases on the World

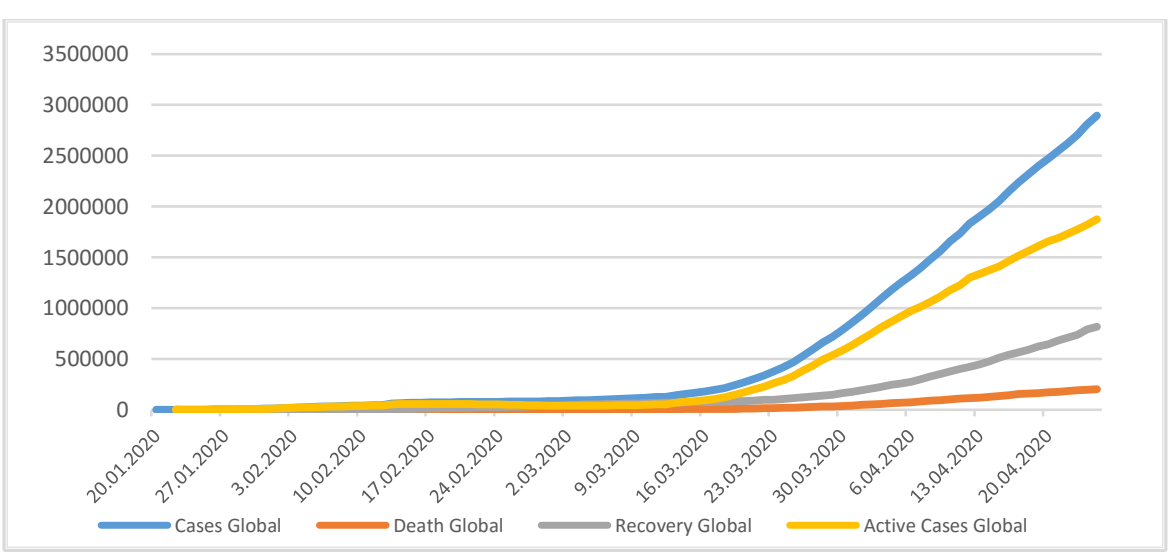

Estimates indicate that about $80 \%$ of people with COVID-19 have mild symptoms or asymptomatic. The most important reason of this estimation is that Covid-19 spread was unrecognised worldwide at the beginning. From December 2019 to May 12 2020, Covid-19 has caused at least 287,670 people's death and has led to physical sicknesses of more than 4,2 million people.

It paralyzed the health systems of the great number of developed and financially wealthy countries in the world. It caused to cease the works of global trade organizations and supply chains. It has led to instability on micro and macroeconomic conditions of countries. Since the physical areas were dangerous to work cooperatively during pandemic, Covid-19 has ceased the economy. It forced people to stay at home and also live under quarantine conditions. (Ozili and Arun, 2020) explain how coronavirus stifled economic activities with two methods. First, the spread of the virus required social distancing to be protected from disease so the financial markets, corporate offices, businesses and events were closed down. Second, the virus was spreading aggressively and there was the fierce ambiguity about how bad the pandemic could get, caused sudden increase in consumption and investment among consumers, investors and international trade partners.

Ercolani and Natoli (2020) indicated that private forecasters estimate the rebound in the $3^{\text {th }}$ quarter of 2020 in the USA and also worldwide. On the other hand, Ercolani and Natoli predicted the recession in the United States will extend.

The purpose of this research is to contribute to the academic field by demonstrating long term and short term impact of Covid-19 virus on stock exchange markets and CDS markets. In this study, as methodology, Johansen Cointegration Test and VECM models are used.

As Covid-19 emerged in December 2019, studies in this area are still very restricted. However, a few authors completed and published their work in this field. For example, (Zeren and Hızarcl, 2020) checked into the effect of the centre countries of Covid-19 epidemic on their stock exchange markets thoroughly. They used Maki (2012) cointegration test as a method which uses both Covid-19 total case and Covid-19 total death number. In conclusion, they noted that all stock markets observed the death of Covid-19 act together in the long term. In addition, the authors indicated that there is a cointegration relationship between total cases of Covid-19 and indexes of stock markets in South Korea, China and Spain. Otherwise, there is no cointegration relationship with stock markets in Italy, France, Germany.

$($ Acar,2020) studied current and future potential impacts of the Covid-19 on tourism activities. Covid-19 will cause long-term damage to the economies of countries including tourism. Tourism will be one of the heavily affected sector by Covid-19. The author stated that the outbreak reduced the global tourist mobility from $1 \%$ to $3 \%$. This downward rate is going to cause 30 to 50 billion USD loss approximately regarding international tourism revenues. 
(Ayittey, Chiwero, Ayittey, Kamasah and Dzuvor, 2020) researched the effect of Covid-19 on Chinese and World Economies. As the authors indicated and estimated that China will lose up to $\$ 62$ billion in January, February and Mach 2020. Besides, according to authors, it is a high probability the world may lose much more than 280 billion $\$$.

(McKibbin, Fernando,2020) studied on the global macroeconomic effects of Covid-19 with seven Scenarios. The authors demonstrated in their scenarios that the Covid-19 might significantly affect the global economy in the short period.

(Ramelli and Wagner, 2020) point out that the market responses to the Covid-19 specify new understandings to explain how real shocks and financial polices convert firm value. Moreover, the authors explained how important financial channels are to state the scale of the expected effects of the health disaster.

(Shaen, Larkin and Brian, 2020) are authors who wrote about Chinese financial markets and COVID-19. They pointed out that the unstable relation between the main Chinese stock markets and Bitcoin developed visibly during the period of immense financial stress. They supplied a number of their observations and conclusions to explain the reason why this situation emerged.

(Ferdandes, 2020) issued a report about the economic influence of the COVID-19 crisis on economy of 30 countries, he uses different scenarios to analyse the economic activities. The author demonstrated in his one scenario that average GDP of 30 countries will decline $-2.8 \%$. In another scenario, GDP can decline more than $10 \%$ or $15 \%$.

\section{DATA AND METHODOLOGY}

In this paper, Johanse and Jeuselius (1990) Cointegration Test was used as the methodology to define the existence of the long-run statistical relationship between Covid-19 data and economic variables of countries. This approach has been well popularized to measure the long-run relationships among variables. The method involves cointegration and the estimation of the Vector Error Correction Model ${ }^{1}$ in order to define the time series behaviour.

The Johansen Cointgreation approach consists of two parts.

In this way, firstly, whether the series are stationary or not is examined using unit root test. Later, Johansen Cointegration test is used in the analysis. Secondly, the lag length criteria will be determined to perform the Johansen Cointegration Test. Finally, Johansen Cointegration test will imply to define the relationship among the variables.

China (CH), France (FR), Germany (GR), Italy (IT), The United States (USA), The United Kingdom (UK), Spain (SP) and Turkey (TR) are the countries where the Covid-19 virus is common in the world. Therefore, stock market indexes (S) and CDS rates (CD) of eight countries were chosen to determine the effect of the virus on the country's economy. Stock market indexes (S) and CDS (CD) market were chosen specifically, because these are extremely sensitive variables to identify the fluctuation of the market. Therefore, they are good variables to measure economic situations as well.

In the part of analysis, all variables are given with their abbreviations in the parentheses. All variables were collected between 22 January 2020 and 25 April 2020 daily. The number of active cases is one of the important data while struggling with pandemic. Because, this variable shows the existence of current number of patients. Therefore, this variable was added in the study. The calculation as below:

Active Cases $(A C A)=$ Confirmed Cases $(C A)-[$ Deaths $(D E)+$ Recovery Cases $(R C A)]$

Covid-19 global data and economic data of the countries has been obtained from the website of Harvard Dataverse ${ }^{2}$ and Investing. $\mathrm{com}^{3}$, respectively. The log-transformation of the raw series were taken in order to standardize them for the relative same rates and the same numerical structure. Moreover, Cointegration Test allows us to use the log-transformation of the research data. Unit root tests must be done for each variable. Because, to carry out Johansen Cointegration test, it is supposed that the series are stationary. In the analysis ADF, DF and PP unit root tests were used to determine the series which were stationary in the level and in the first log difference or not.

\footnotetext{
${ }^{1}$ VECM

${ }^{2}$ https://dataverse.harvard.edu/

3 https://www.investing.com/
} 
After the all variables were determined as stationary in the first differences, their lag length criteria must be defined to perform the Johansen Cointegration Test. Thus, $\mathrm{LR}^{4}, \mathrm{FPE}^{5}, \mathrm{AlC}^{6}, \mathrm{SC}^{7}$ and $\mathrm{HQ}^{8}$ criteria were employed to determine the most appropriate delay length.

After the most appropriate delay length was determined, the number of cointegration ranks $(r$ ) were tested via The Maximum Eigenvalue and Trace Test. From the theoretical, intuitive, and empirical discussion, the relationship between Covid-19 data and selected stock market variables and CDS prices were postulated as described as follows:

$\ln (C A)_{t}=\beta_{0}+\ln \beta_{1}(S)+\xi_{t}$

$\ln (S)_{t}=\beta_{0}+\ln \beta_{1}($ Covid19_Death $)+\xi_{t}$

$\beta_{0}$ is a constant, $\beta_{1}$ is the sensitivity of each of the Covid-19 cases or death variables to stock prices and $\xi_{t}$ is a stationary error correction term.

Johansen Cointegration test (Johanse and Juselius, 1990) was applied to determine the existence of long term relationship between Covid-19 data and economic variables so they are at the same level stationarity. The number of cointegration vectors in the variables were defined.

Johansen's approach proceeds its beginning point in the VAR of order $p$ as follow

$$
Y_{t}=\mu+\lambda_{1} \cdot Y_{t-1}+\lambda_{2} \cdot Y_{t-2} \cdots \cdots \cdots \cdots \cdots \cdots \cdots+\lambda_{k} Y_{t-k}+e_{t}
$$

The VAR can be expressed again in dynamic shape as follow

$\Delta Y_{t}=\mu+\sum_{i=1}^{k} \lambda_{i} \Delta Y_{t-i}+e_{t}$

In Equation 6, $Y_{t}$ is a $p \times 1$ vector of integrated variables in an equation, $\lambda_{k}$ is a $p \times 1$ matrix of values, et is a $p \times 1$ vector of stochastic period and $p$ is the number of rows in a matrix.

The matrix $\lambda$ contains data about the long-term properties of the model. If $\lambda$ has rank zero, $r$ indicates the number of cointegrating vectors, at that point the system isn't cointegrated. If $\lambda$ has rank $p$, all the variables in $Y_{t}$ are stationary and are all cointegrated, demonstrating the long-term relationship between the exploration variables.

The test statistics for cointegration are formulated as

$\lambda_{\text {trace }}(r)=-T \sum_{i=r+1}^{g} \ln \left(1-\lambda_{i}\right)$

$\lambda_{\max }(r, r+1)=-T \ln \left(1-\lambda_{r+i}\right)$

$\lambda_{\text {trace }}$ tests the null the number of cointegration vectors is less than or equal to $(r)$ against an unspecified alternative.

$\lambda_{\text {max }}$ tests the null the number of cointegration vectors is $(r)$ against is alternative of $(r+1)$

The Johansen test is a test for cointegration of several I(1) time series data.

Oseni and Onakoya (2012) described the error correction as follow:

$e_{t}=Y_{t}-\beta X_{t}$

Where: $\beta$ is a cointegrating coefficient and $\mathrm{e}_{\mathrm{t}}$ is the error from a regression of $Y_{t}$ on $X_{t}$. ECM is basically described as:

\footnotetext{
${ }^{4}$ Likelihood

${ }^{5}$ Final Prediction Error

${ }^{6}$ Akaike Information Criterion

${ }^{7}$ Schwarz Information Criterion

${ }^{8}$ Hannan-Quinn Information Criterion
} 
$\Delta Y_{t}=\alpha e_{t-1}+\gamma \Delta X_{t}+u_{t} \ldots \ldots \ldots$

Where: $u_{t}$ is iid, $e_{t-1}$ the equilibrium error occurred in the earlier period, $\alpha$ and $\gamma$ are short term constraints.

VECM: $\Delta y_{t}=\beta_{0}+\sum_{i=1}^{n} \beta_{i} \Delta y_{t-i}+\sum_{i=0}^{n} \delta_{i} \Delta x_{t-i}+\varphi z_{t-1}+\mu_{t}$

Cointegration eq.: $z_{t-1}=E C T_{t-1}=y_{t-1}-\beta_{0}-\beta_{1} x_{t-1}$ long run model

If time series are non-stationary but I(1) the time series are cointegrated, the VECM can be used to examine both the long and short term dynamics of the series.

\section{FINDINGS AND DISCUSSIONS}

\subsection{Correlations}

Preliminary results in the Table 3 and Table 4 additionally motivates the search of possible relation between Covid-19 and stock markets with Credit Default Swaps.

As expected, there is a negative high correlation between Cases, Death of Covid-19 and stock markets. The range of the correlations is from -0.45 (between Cases and SSEC) to -0.78 (between Death and IBEX 35) as seen in Table 3 . In the same way, the range of the correlations is from 0,26 (between Cases and DJI) to 0.89 (between Deaths and BIST 100) as seen in Table 4.

Table 3: Correlation Matrix between Covid-19 Data and Stock Markets

\begin{tabular}{|lccc|}
\hline Markets & $\begin{array}{c}\text { Glock } \\
\text { Cases }\end{array}$ & $\begin{array}{c}\text { Global } \\
\text { Deaths }\end{array}$ & $\begin{array}{c}\text { Global Active } \\
\text { Cases }\end{array}$ \\
\hline SEC & -0.45 & -0.46 & -0.50 \\
CAC 40 & -0.74 & -0.76 & -0.71 \\
DAX & -0.68 & -0.70 & -0.64 \\
FTSE MIB & -0.74 & -0.77 & -0.71 \\
DJI & -0.60 & -0.61 & -0.58 \\
FTSE 100 & -0.75 & -0.77 & -0.72 \\
IBEX 35 & -0.76 & -0.78 & -0.74 \\
BIST 100 & -0.75 & -0.77 & -0.73 \\
\hline
\end{tabular}

Table 4: Correlation Matrix between Covid-19 Data and CDS Price

\begin{tabular}{|lccc|}
\hline $\begin{array}{l}\text { Credit Default } \\
\text { Swap (CDS) }\end{array}$ & $\begin{array}{c}\text { Global } \\
\text { Cases }\end{array}$ & $\begin{array}{c}\text { Global } \\
\text { Deaths }\end{array}$ & $\begin{array}{c}\text { Global } \\
\text { Active Cases }\end{array}$ \\
\hline China & 0.45 & 0.47 & 0.38 \\
France & 0.79 & 0.82 & 0.79 \\
Germany & 0.75 & 0.79 & 0.75 \\
Italy & 0.65 & 0.68 & 0.60 \\
USA & 0.26 & 0.27 & 0.33 \\
UK & 0.82 & 0.84 & 0.82 \\
Spain & 0.78 & 0.81 & 0.77 \\
Turkey & 0.86 & 0.89 & 0.84 \\
\hline
\end{tabular}


As seen in Figure 2, It is clear that volatility of the Stock Market increased relatively in February and March. As seen figure 3, the volatility of CDS price increased in March and April sharply.

Figure 2: Return of Stock Indexes

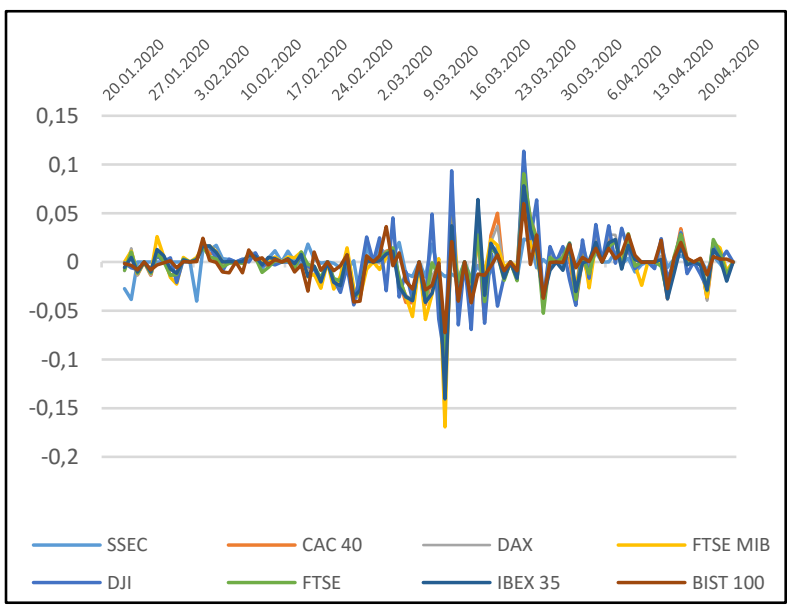

Figure 3: Five Years Credit Default Swaps (CDS) of Countries

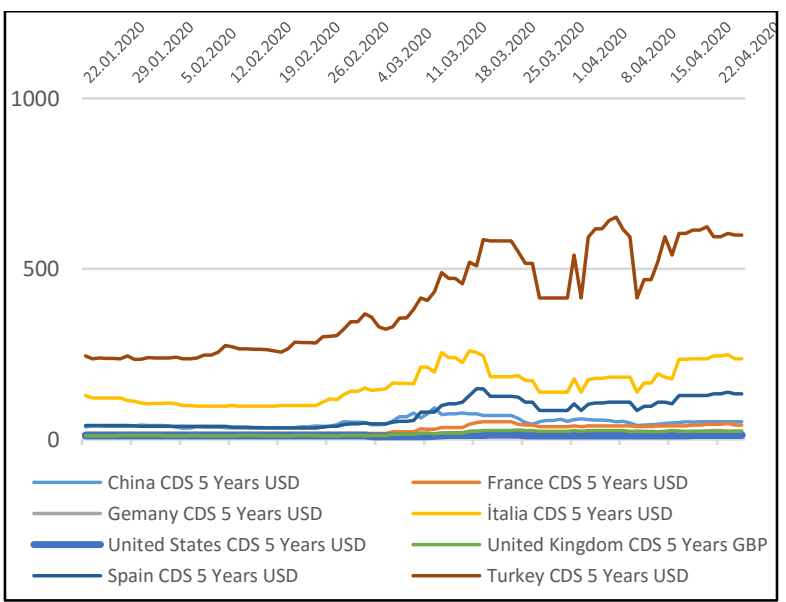

\subsection{Unit Root Test}

ADF, DF and PP unit root tests were used. All of Covid-19 data, country stock market and CDS market data have unit roots in the level. However, they became stationary after taking the first difference as seen in table 5 .

Table 5: ADF, DF-GLS and PP Unit Root Test Results- First Difference

\begin{tabular}{|c|c|c|c|c|c|c|c|c|c|c|c|}
\hline \multicolumn{12}{|c|}{ LEVEL } \\
\hline & $\begin{array}{l}\text { Total } \\
\text { Cases }\end{array}$ & $\begin{array}{l}\text { Total } \\
\text { Death }\end{array}$ & $\begin{array}{l}\text { Active } \\
\text { Cases }\end{array}$ & SSEC & CAC 40 & DAX & FTSE MIB & DJI & FTSE 100 & IBEX 35 & BIST 100 \\
\hline N obs. & 95 & 95 & 95 & 95 & 95 & 95 & 95 & 95 & 95 & 95 & 95 \\
\hline$A D F$ & $-2,06$ & $-2,13$ & $-0,91$ & $-2,33$ & $-1,41$ & $-2,95$ & $-2,46$ & $-7,00^{* * *}$ & $-1,68$ & $-1,51$ & $-8,18^{* * *}$ \\
\hline DF-GLS & 0,72 & 0,76 & 0,44 & $-0,88$ & $-0,78$ & $-1,73$ & $-2,03^{* *}$ & $-3,91^{* * *}$ & $-1,01$ & $-0,97$ & $-7,55^{* * *}$ \\
\hline PP & $-3,99^{* *}$ & $-3,51^{* * *}$ & $-2,98^{* *}$ & $-2,44$ & $-1,60$ & $-4,64$ & $-5,40^{* * *}$ & $-7,23^{* * *}$ & $-2,74 *$ & $-2,67^{*}$ & 7,50 \\
\hline \multicolumn{12}{|c|}{$1^{\text {st }}$ LEVEL } \\
\hline & $\begin{array}{l}\text { Total } \\
\text { Cases }\end{array}$ & $\begin{array}{l}\text { Total } \\
\text { Death }\end{array}$ & $\begin{array}{l}\text { Active } \\
\text { Cases }\end{array}$ & SSEC & CAC 40 & DAX & FTSE MIB & DJI & FTSE 100 & IBEX 35 & BIST 100 \\
\hline ADF & $-2,73^{*}$ & $-3,16^{* *}$ & $-2,84^{*}$ & $-10,00^{* * *}$ & $-14,13^{* * *}$ & $-11,02^{* * *}$ & $11,28^{* * *}$ & $-11,00^{* * *}$ & $-10,68^{* * *}$ & $-10,77^{* * *}$ & $-9,27^{* * *}$ \\
\hline DF-GLS & $-2,27^{* *}$ & $-3,19^{* * *}$ & $-1,92^{*}$ & $-3,77^{* * *}$ & $-14,12^{* * *}$ & $-11,06^{* * *}$ & $-11,34^{* * *}$ & $-11,06^{* * *}$ & $-10,67^{* * *}$ & $-10,79^{* * *}$ & $-9,32^{* * *}$ \\
\hline PP & $-4,38^{* * *}$ & $-4,94^{* * *}$ & $-4,17^{* * *}$ & $-10,04^{* * *}$ & $-15,41^{* * *}$ & $-30,29^{* * *}$ & $-41,71^{* * *}$ & $-42,53^{* * *}$ & $-24,40^{* * *}$ & $-25,58^{* * *}$ & $-81,91^{* * *}$ \\
\hline
\end{tabular}

\subsection{Cointegration Tests and VECM Model of the Countries}

\subsubsection{China}

Estimated Cointegration test (Juselius and Johangsen,1987) with lag length of 5 and Model 1 for China. 
Table 6: Johansen Cointegration Test (1988) Results for China

\begin{tabular}{|l|ccc|}
\hline & Trace Val. & Critic. Val. & Pro. \\
\hline None* $(r=0)$ & 137.93 & 76.97 & 0.0000 \\
At most one* $(r \leq 1)$ & 66.28 & 54.08 & 0.0028 \\
At most two $(r \leq 2)$ & 36.82 & 35.19 & 0.0331 \\
At most three $(r \leq 3)$ & 17.30 & 20.26 & 0.1217 \\
At most four $(r \leq 4)$ & 7.51 & 9.16 & 0.1021 \\
\hline Hypothesized No of CEs & Max.Eg.Val. & Critic. Val. & Pro. \\
\hline None* $(r=0)$ & 71.66 & 34.81 & 0.0000 \\
At most one* $(r \leq 1)$ & 29.46 & 28.59 & 0.0386 \\
At most two $(r \leq 2)$ & 19.52 & 22.30 & 0.1170 \\
At most three $(r \leq 3)$ & 9.79 & 15.89 & 0.3536 \\
At most four $(r \leq 4)$ & 7.51 & 9.16 & 0.1021 \\
\hline
\end{tabular}

Note:* This sign indicates that the hypothesis is rejected at $\% 5$ level.

Table 6 demonstrates the results of the Johansen Cointegration Test. In the table, trace statistics indicated three cointegrating vectors. The trace value is 137,93 and it is greater than $5 \%$ critical value. The Max_Eigen statistics also indicated two cointegrating vectors. In the same way, the maximum Eigen-value is greater than $5 \%$ critical value.

The results clearly state that the number of cases of Covid-19 is long-run determinants of financial markets in China.

If the variables are cointegarted or expressing in other words, the variables have long term relationship, then restricted a Vector autoregressive (VAR) can be run and this method is called as VECM Model. On the other hand, if the variables are not cointegareted, VECM model cannot be run, instead unrestricted VAR can be applied.

After cointegarted association is determined, the short-run model, VAR, is used. This model was estimated by

$$
\begin{aligned}
& \Delta C A_{t}=-062 e c t_{t-1}-1,11 \Delta C A_{t-1}+0,35 \Delta C A_{t-2}-, 49 \Delta C A_{t-3}-, 84 \Delta C A_{t-4}+1,36 \Delta C A_{t-5}+0,91 \Delta A C A_{t-1}- \\
& 0,01 \Delta A C A_{t-2}+0,08 \Delta A C A_{t-3}-0,63 \Delta A C A_{t-4}-0,82 \Delta A C A_{t-5}+0,09 \Delta D E_{t-1}-0,22 \Delta D E_{t-2}+0,56 \Delta D E_{t-3}- \\
& 0,29 \Delta D E_{t-4}-0,64 \Delta D E_{t-5}-0,12 \Delta S C H_{t-1}+0,08 \Delta S C H_{t-2}-0,33 \Delta S C H_{t-3}-1,36 \Delta S C H_{t-4}-0,37 \Delta S C H_{t-5}- \\
& 0,13 \Delta C D C H_{t-1}-0,04 \Delta C D C H_{t-2}-0,15 \Delta C D C H_{t-3}-0,08 \Delta C D C H_{t-4}-0,15 \Delta C D C H_{t-5}
\end{aligned}
$$

Equation 13 is thelong-run model. The model resulted with a cointegrating vector.

$e c t_{t-1}=C A_{t-1}+104,94 S C H_{t-1}+6,55 C D C H_{t-1}-875$

\section{Table 7: Vector Error Correction Model}

\begin{tabular}{|c|c|c|c|c|}
\hline The Var. & Coeff. & Std. Er. & t-Sta. & Prob. \\
\hline$C(1)$ & -0.616633 & 0.151633 & -4.066615 & 0.0001 \\
\hline
\end{tabular}

$C(1)$ displays the Error Correction Term in table 7. The coefficient value of $C(1)$ is negative and it is statistically significant. It confirms that there is the long run causality from ACA, DE, ST and CD to CA. In addition, $R^{2}$ rate is \%82,4. This confirms that the model is fit and has a good analytical power.

\section{Table 8: Walt Test}

\begin{tabular}{|c|c|c|c|}
\hline Test Statistics & The Variable & Value & Probability \\
\hline Chi-square & DE & 31,22 & 0,0000 \\
\hline Chi-square & ACA & 15,53 & 0,0083 \\
\hline Chi-square & CDCH & 6,59 & 0,2525 \\
\hline Chi-square & SCH & 8,80 & 0,1169 \\
\hline
\end{tabular}


The probability of the Chi-square test is less than \%5. That means that there is the short run causality running from DE and ACA to $\mathrm{CA}$. Otherwise, there is no short run causality running from $\mathrm{CDCH}$ and $\mathrm{SCH}$ to $\mathrm{CA}$ in China.

\subsubsection{France}

Cointegration test was carried out with lag length of 6 and Model 1 for France.

Table 9: Johansen Cointegration Test (1988) Results for France

\begin{tabular}{|l|ccc|}
\hline Hypothesized Number of CEs & Trace Val. & Critic. Val. & Pro. \\
\hline None* $(r=0)$ & 123.29 & 76.97 & 0.0000 \\
At most one* $(r \leq 1)$ & 73.70 & 54.08 & 0.0004 \\
At most two $*(r \leq 2)$ & 41.10 & 35.19 & 0.0103 \\
At most three $(r \leq 3)$ & 22.83 & 20.26 & 0.0217 \\
At most four $(r \leq 4)$ & 9.14 & 9.16 & 0.0505 \\
\hline Hypothesized Number of CEs & Max.Eg.Val. & Critic. Val. & Pro. \\
\hline None* $(r=0)$ & 49.60 & 34.81 & 0.0005 \\
At most one* $(r \leq 1)$ & 32.60 & 28.59 & 0.0145 \\
At most two $(r \leq 2)$ & 18.27 & 22.30 & 0.1664 \\
At most three $(r \leq 3)$ & 13.69 & 15.89 & 0.1076 \\
At most four $(r \leq 4)$ & 9.14 & 9.16 & 0.0505 \\
\hline
\end{tabular}

Note: * This sign displays, the hypothesis is rejected at $\% 5$ level.

In table 9, trace value shows four cointegrating equations. They are more than $5 \%$ critical values. In the same way, the Max_Eigen value is more than $\% 5$ and it indicates two cointegrating equations. The results demonstrate the existences of the long run association between Covid-19 (CA) and financial markets (S and CD).

Equation 14 demonstrates Estimated VECM with CA as target variable.

$$
\begin{aligned}
\Delta C A_{t}=-0,06 e c t_{t-1} & -0,21 \Delta C A_{t-1}-, 40 \Delta C A_{t-2}-0,14 \Delta C A_{t-3}+0,764 \Delta C A_{t-4}+0,68 \Delta C A_{t-5}+0,06 \Delta C A_{t-6} \\
& +0,14 \Delta A C A_{t-1}+0,31 \Delta A C A_{t-2}-0,002 \Delta A C A_{t-3}-0,50 \Delta A C A_{t-4}-0,40 \Delta A C A_{t-5}-0,02 \Delta A C A_{t-6} \\
& +0,58 \Delta D E_{t-1}+0,16 \Delta D E_{t-2}+0,18 \Delta D E_{t-3}-0,35 \Delta D E_{t-4}-0,17 \Delta D E_{t-5}+0,12 \Delta D E_{t-6}-0,20 \Delta S F R_{t-1} \\
& -0,02 \Delta S F R_{t-2}-0,05 \Delta S F R_{t-3}-0,15 \Delta S F R_{t-4}-0,22 \Delta S F R_{t-5}-0,12 \Delta S F R_{t-6}-0,12 \Delta C D F R_{t-1} \\
& -0,019 \Delta C D F R_{t-2}-0,11 \Delta C D F R_{t-3}-0,07 \Delta C D F R_{t-4}-0,13 \Delta C D F R_{t-5}-0,10 \Delta C D F R_{t-6}
\end{aligned}
$$

Equation 15 shows Cointegration Equation for long run model.

$e c t_{t-1}=C A_{t-1}+A C A_{t-1}+D E_{t-1}+S F R_{t-1}+C D F R_{t-1}$

Table 10: Vector Error Correction Model

\begin{tabular}{|c|c|c|c|c|}
\hline The Var. & Coeff. & Std. Er. & t-Sta. & Prob. \\
\hline$C(1)$ & $-0,06$ & 0,1111 & $-0,5813$ & 0,5634 \\
\hline
\end{tabular}

In table 10 , the coefficient of $C(1)$ has negative value but its probability is more than \%5. It means that it isn't significant. Therefore, it can't be said the existence of the long run causality from ACA, DE, ST and CD to CA. In addition, $R^{2}$ is $\% 78,04$. This is a pretty good rate to confirm the explanatory power of this model.

\section{Table 11: Walt Test}

\begin{tabular}{|c|c|c|c|}
\hline Test Statistics & The Variable & Value & Probability \\
\hline Chi-square & DE & 10,60 & 0,1015 \\
\hline Chi-square & ACA & 3,57 & 0,7344 \\
\hline Chi-square & CDFR & 6,64 & 0,3552 \\
\hline Chi-square & SFR & 2,63 & 0,8539 \\
\hline
\end{tabular}


As seen in table 11 , the probability of the test is less than 0,05 . It indicates that there is short run causality running from $D E$ and ACA to CA. Conversely, it can't be said the existence the short term causality which run from CD and S to CA.

\subsubsection{Germany}

Cointegration test was used with lag length of 2 and Model 2 for Germany.

Table 12: Johansen Cointegration Test (1988) Results for France.

\begin{tabular}{|l|ccc|}
\hline Hypothesized Number of CEs & Trace Val. & Critic. Val. & Pro. \\
\hline None* $(r=0)^{\text {At most one* }(r \leq 1)}$ & 100.55 & 76.97 & 0.0003 \\
At most two $(r \leq 2)$ & 54.29 & 54.08 & 0.0479 \\
At most three $(r \leq 3)$ & 30.00 & 35.19 & 0.1632 \\
At most four $(r \leq 4)$ & 9.17 & 20.26 & 0.7206 \\
\hline Hypothesized Number of CEs & 3.97 & 9.16 & 0.4162 \\
\hline None* $(r=0)$ & Max.Eg.Val. & Critic. Val. & Pro. \\
At most one $(r \leq 1)$ & 46.26 & 34.81 & 0.0014 \\
At most two $(r \leq 2)$ & 24.29 & 28.59 & 0.1608 \\
At most three $(r \leq 3)$ & 20.83 & 22.30 & 0.0791 \\
At most four $(r \leq 4)$ & 5.19 & 15.89 & 0.8710 \\
\hline
\end{tabular}

Note:* This sign displays, the hypothesis is rejected at $\% 5$ level.

As seen table 12, both Trace value and The Max_Eigen value demonstrate two cointegrating equations which are other important results, because these information might be beneficial to predict long run forecast about Covid-19 and financial markets.

Equation 16 demonstrates Estimated VECM with CA as target variable.

$$
\begin{gathered}
\Delta C A_{t}=-0,3 e c t_{t-1}-0,62 \Delta C A_{t-1}+0,49 \Delta C A_{t-2}+0,44 \Delta A C A_{t-1}+0,006 \Delta A C A_{t-2}+0,08 \Delta D E_{t-1}-0,44 \Delta D E_{t-2} \\
-0,29 \Delta S G R_{t-1}+0,19 \Delta S G R_{t-2}-0,16 \Delta C D G R_{t-1}+0,002 \Delta C D G R_{t-2}
\end{gathered}
$$

Equation 17 shows Cointegration Equation for long term model.

$e c t_{t-1}=A C A_{t-1}+C A_{t-1}-0,92 D E_{t-1}-0,48 S G R_{t-1}-0,72 C D G R_{t-1}-0,088$

Table 13: Vector Error Correction (VECM) Model

\begin{tabular}{|c|c|c|c|c|}
\hline The Var. & Coeff. & Std. Er. & t-Sta. & Prob. \\
\hline$C(1)$ & $-0,3154$ & 0,0699 & $-4,5095$ & 0,0000 \\
\hline
\end{tabular}

In table 13 , the coefficient value is $-0,3154$ which is negative and significant as well. Therefore, it can be accepted the probability or existence as the long term causality from ACA, DE, SGR and CDGR to CA. In addition, $R^{2}$ is $\% 77,8$. This ratio specifies that the model has an adequate explanatory power.

\section{Table 14: Walt Test}

\begin{tabular}{|c|c|c|c|}
\hline Test Statistics & The Variable & Value & Probability \\
\hline Chi-square & DE & 6,77 & 0,0337 \\
\hline Chi-square & ACA & 1,65 & 0,4362 \\
\hline Chi-square & CDGR & 3,34 & 0,1883 \\
\hline Chi-square & SGR & 2,26 & 0,3229 \\
\hline
\end{tabular}


As seen in Table 14, the probability of the test is less than $\% 5$ for only variable DE which means, there is short run causality running from DE to CA. Conversely, it can't be said for the existence of the short run causality from ACA, CDGR and SGR to CA.

\subsubsection{Italy}

Cointegration Test is used with lag length of 6 and Model 2 for Italy. The result of the Johansen Test was demonstrated as follows.

Table 15: Johansen Cointegration Test (1988) Results for France

\begin{tabular}{|l|ccc|}
\hline Hypothesized Number of CEs & Trace Val. & Critic. Val. & Pro. \\
\hline None* $(r=0)$ & 127.46 & 76.97 & 0.0000 \\
At most one* $(r \leq 1)$ & 84.86 & 54.08 & 0.0000 \\
At most two* $(r \leq 2)$ & 47.47 & 35.19 & 0.0015 \\
At most three* $(r \leq 3)$ & 24.08 & 20.26 & 0.0142 \\
At most four $(r \leq 4)$ & 5.03 & 9.16 & 0.2804 \\
\hline Hypothesized Number of CEs & Max.Eg.Val. & Critic. Val. & Pro. \\
\hline None* $(r=0)$ & 42.60 & 34.81 & 0.0048 \\
At most one* $(r \leq 1)$ & 37.39 & 28.59 & 0.0029 \\
At most two* $(r \leq 2)$ & 23.39 & 22.30 & 0.0351 \\
At most three* $(r \leq 3)$ & 19.05 & 15.89 & 0.0154 \\
At most four $(r \leq 4)$ & 5.03 & 9.16 & 0.2804 \\
\hline
\end{tabular}

Note:* This sign displays the hypothesis is rejected at $\% 5$ level.

Trace and the Max_Eigen statistics figure out the indication of four cointegrating vectors. The trace value is 24,08 and it is more than the critical value $(20,26)$. Likewise, The Max_Eigen value is 19,05 which is more than the critical value $(15,89)$. Consequently, it can be said that there is long run relationship between Covid-19 cases and financial markets.

Equation 18 determines Estimated VECM with CA as target variable.

$\Delta C A_{t}=0,20 e c t_{t-1}+0,01 \Delta C A_{t-1}-, 28 \Delta C A_{t-2}-0,15 \Delta C A_{t-3}+0,21 \Delta C A_{t-4}+0,50 \Delta C A_{t-5}+0,06 \Delta C A_{t-6}+$ $0,35 \Delta A C A_{t-1}+0,39 \Delta A C A_{t-2}-0,0003 \Delta A C A_{t-3}-0,004 \Delta A C A_{t-4}-0,12 \Delta A C A_{t-5}+0,06 \Delta A C A_{t-6}-0,75 \Delta D E_{t-1}-$ $0,16 \Delta D E_{t-2}-0,28 \Delta D E_{t-3}-0,42 \Delta D E_{t-4}-0,31 \Delta D E_{t-5}+0,06 \Delta D E_{t-6}-0,20 \Delta S_{t-1}-0,02 \Delta T_{t-2}-0,33 \Delta S I T_{t-3}+$ $0,17 \Delta S I T_{t-4}+0,17 \Delta S I T_{t-5}+0,09 \Delta S I T_{t-6}+0,10 \Delta C D I T_{t-1}-0,08 \Delta C D I T_{t-2}+0,08 \Delta C D I T_{t-3}+0,07 \Delta C D I T_{t-4}+$ $0,006 \Delta C D I T_{t-5}+-0,003 \Delta C D I T_{t-6}$

Equation 19 displays Cointegration Equation for long run model.

$$
e c t_{t-1}=A C A_{t-1}+C A_{t-1}++D E_{t-1}+8,36 S I T_{t-1}+C D I T_{t-1}-95,04
$$

Table 16: Vector Error Correction Model

\begin{tabular}{|c|c|c|c|c|}
\hline The Var. & Coeff. & Std. Er. & t-Sta. & Prob. \\
\hline$C(1)$ & 0,1447 & 0,1000 & 1,4465 & 0,1538 \\
\hline
\end{tabular}

Table 16 displays that coefficient value of $C(1)$ is positive in sign but it isn't significant, then it can't be assumed that there is long run causality running from $A C A, D E, S T$ and $C D$ to $C A$. In addition, $R^{2}$ of the model is $\% 79,6$. That indicates that the model is fit. 
Table 17: Walt Test

\begin{tabular}{|c|c|c|c|}
\hline Test Statistics & The Variable & Value & Probability \\
\hline Chi-square & DE & 8,41 & 0,2089 \\
\hline Chi-square & ACA & 1,26 & 0,9700 \\
\hline Chi-square & CDIT & 3,82 & 0,7004 \\
\hline Chi-square & SIT & 2,37 & 0,8827 \\
\hline
\end{tabular}

The probability of all tests is more than $\% 5$. That means that null hypothesis can be accepted there is no short run causality running from DE, ACA, CDIT and SIT to CA.

\subsubsection{United States}

Cointegration test was calculated with lag length of 6 and Model 2 for United States.

Table 18: Johansen Cointegration Test (1988) Results for France

\begin{tabular}{|l|ccc|}
\hline Hypothesized Number of CEs & Trace Val. & Critic. Val. & Pro. \\
\hline None* $\left.^{*} r=0\right)$ & 151.65 & 76.97 & 0.0000 \\
At most one* $(r \leq 1)$ & 84.55 & 54.08 & 0.0000 \\
At most two* $(r \leq 2)$ & 49.68 & 35.19 & 0.0007 \\
At most three* $(r \leq 3)$ & 24.04 & 20.26 & 0.0144 \\
At most four $(r \leq 4)$ & 4.57 & 9.16 & 0.3345 \\
\hline Hypothesized Number of CEs & Max.Eg.Val. & Critic. Val. & Pro. \\
\hline None* $(r=0)$ & 67.10 & 34.81 & 0.0000 \\
At most one* $(r \leq 1)$ & 34.87 & 28.59 & 0.0069 \\
At most two* $(r \leq 2)$ & 25.64 & 22.30 & 0.0164 \\
At most three* $(r \leq 3)$ & 19.47 & 15.89 & 0.0131 \\
At most four $(r \leq 4)$ & 4.57 & 9.16 & 0.3345 \\
\hline
\end{tabular}

Note:* This sign displays, the hypothesis is rejected at $\% 5$ level.

From the Table 20, Trace and the Max_Eigen statistics displays four cointegrating vectors.

$\Delta C A_{t}=0,34 e c t_{t-1}-0,16 \Delta C A_{t-1}-0,59 \Delta C A_{t-2}-0,53 \Delta C A_{t-3}+0,08 \Delta C A_{t-4}+0,38 \Delta C A_{t-5}-0,33 \Delta C A_{t-6}+$ $0,35 \Delta A C A_{t-1}+0,39 \Delta A C A_{t-2}-0,0003 \Delta A C A_{t-3}-0,004 \Delta A C A_{t-4}-0,16 \Delta A C A_{t-5}+0,29 \Delta A C A_{t-6}-0,35 \Delta D E_{t-1}+$ $0,60 \Delta D E_{t-2}+0,43 \Delta D E_{t-3}-0,03 \Delta D E_{t-4}+0,017 \Delta D E_{t-5}-0,04 \Delta D E_{t-6}-0,15 \Delta S U S_{t-1}-0,08 \Delta S U S_{t-2}-0,06 \Delta S U S_{t-3}+$ $0,17 \Delta S U S_{t-4}+0,17 \Delta S U S_{t-5}+0,09 \Delta S U S_{t-6}-0,13 \Delta C D U S_{t-1}-0,09 \Delta C D U S_{t-2}-0,18 \Delta C D U S_{t-3}+0,07 \Delta C D U S_{t-4}+$ $0,006 \Delta C D U S_{t-5}+-0,003 \Delta C D U S_{t-6}$

Equation 21 displays Cointegration Equation for long run model.

$e c t_{t-1}=A C A_{t-1}+C A_{t-1}++D E_{t-1}+38,8 S U S_{t-1}+C D U S_{t-1}-406,66$

Table 19: Vector Error Correction Model

\begin{tabular}{|c|c|c|c|c|}
\hline The Var. & Coeff. & Std. Er. & t-Sta. & Prob. \\
\hline$C(1)$ & 0,1447 & 0,1000 & 1,4465 & 0,1538 \\
\hline
\end{tabular}

In table 19, the coefficient value of $C(1)$ is positive in sign but it isn't significant. Therefore, it can't be said the existence of long run causality from ACA, DE, STUS and CDUS to CA. In addition, $R^{2}$ is $\% 79,6$. That means, the model is fit. 
Table 20: Walt Test

\begin{tabular}{|c|c|c|c|}
\hline Test Statistics & The Variable & Value & Probability \\
\hline Chi-square & DE & 8,41 & 0,2089 \\
\hline Chi-square & ACA & 1,26 & 0,9700 \\
\hline Chi-square & CDIT & 3,82 & 0,7004 \\
\hline Chi-square & SIT & 2,37 & 0,8827 \\
\hline
\end{tabular}

In table 20 , all probability is greater than $\% 5$. Therefore, it is clearly said that there is no short run causality running from DE, ACA, CDIT and SIT to CA.

\subsubsection{The United Kingdom}

Cointegration test was analysed with lag length of 2 and no trend \& no intercept model.

Table 21: Johansen Cointegration Test (1988) Results for France

\begin{tabular}{|l|ccc|}
\hline Hypothesized Number of CEs & Trace Val. & Critic. Val. & Pro. \\
\hline None* $(r=0)$ & 110.87 & 76.97 & 0.0000 \\
At most one* $(r \leq 1)$ & 69.64 & 54.08 & 0.0011 \\
At most two $(r \leq 2)$ & 34.48 & 35.19 & 0.0596 \\
At most three $(r \leq 3)$ & 12.90 & 20.26 & 0.3722 \\
At most four $(r \leq 4)$ & 2.63 & 9.16 & 0.6518 \\
\hline Hypothesized Number of CEs & Max.Eg.Val. & Critic. Val. & Pro. \\
\hline None* $(r=0)$ & 41.23 & 34.81 & 0.0075 \\
At most one* $(r \leq 1)$ & 35.16 & 28.59 & 0.0062 \\
At most two $(r \leq 2)$ & 21.58 & 22.30 & 0.0627 \\
At most three $(r \leq 3)$ & 10.27 & 15.89 & 0.3108 \\
At most four $(r \leq 4)$ & 2.63 & 9.16 & 0.6518 \\
\hline
\end{tabular}

Note:* This sign displays, the hypothesis is rejected at $\% 5$ level.

From Table 21 , the trace value $(69,64)$ is more than the critical values $(54,08)$. Also, The Max_Eigen value $(35,16)$ is more than critical value $(28,59)$. As a result, both tests indicate 2 cointregration vectors.

$$
\begin{gathered}
\Delta C A_{t}=-0,29 e c t_{t-1}-0,67 \Delta C A_{t-1}+0,68 \Delta C A_{t-2}+0,52 \Delta A C A_{t-1}-0,07 \Delta A C A_{t-2}+0,14 \Delta D E_{t-1}-0,63 \Delta D E_{t-2} \\
-0,10 \Delta S U K_{t-1}+0,10 \Delta S U K_{t-2}-0,09 \Delta C D U K_{t-1}-0,05 \Delta C D U K_{t-2}
\end{gathered}
$$

Equation 23 displays Cointegration Equation for long run model.

$e c t_{t-1}=A C A_{t-1}+C A_{t-1}+0,74 D E_{t-1}-13,88 S U K_{t-1}-12,44 C D U K_{t-1}+135,41$

\section{Table 22: Vector Error Correction Model}

\begin{tabular}{|c|c|c|c|c|}
\hline The Variable & Coefficient & $\begin{array}{c}\text { Standard } \\
\text { Error }\end{array}$ & t-Statistic & Probability \\
\hline$C(1)$ & $-0,2991$ & 0,0856 & $-3,4913$ & 0,0008 \\
\hline
\end{tabular}

The coefficient value of $C(1)$ variable is negative sign and significant. It means that there is long run causality running from ACA, $D E$, SUK and CDUK to CA. In addition, $\mathrm{R}^{2}$ is of the model is $\% 75,1$ which shows the model is fit. 
Table 23: Walt Test

\begin{tabular}{|c|c|c|c|}
\hline Test Statistics & The Variable & Value & Probability \\
\hline Chi-square & DE & 13,47 & 0,0012 \\
\hline Chi-square & ACA & 3,21 & 0,2006 \\
\hline Chi-square & CDUK & 0,75 & 0,6867 \\
\hline Chi-square & SUK & 0,36 & 0,8335 \\
\hline
\end{tabular}

All test probability is greater than $\% 5$ except DE. Therefore, it can be said that there is no short run causality running from ACA, CDUK and SUK to CA. Otherwise, the existence the short term connection running from DE to CA is clear.

\subsubsection{Spain}

Cointegration test is used with lag length of 2 and Model 2 for Spain.

Table 24: Johansen Cointegration Test (1988) Results for Spain

\begin{tabular}{|l|ccc|}
\hline Hypothesized Number of CEs & Trace Val. & Critic. Val. & Pro. \\
\hline None* $(r=0)^{\text {At most one* }(r \leq 1)}$ & 127.05 & 76.97 & 0.0000 \\
At most two $(r \leq 2)$ & 68.66 & 54.08 & 0.0015 \\
At most three $(r \leq 3)$ & 30.67 & 35.19 & 0.1420 \\
At most four $(r \leq 4)$ & 10.20 & 20.26 & 0.6198 \\
\hline Hypothesized Number of CEs & 4.95 & 9.16 & 0.2894 \\
\hline None* $(r=0)$ & Max.Eg.Val. & Critic. Val. & Pro. \\
At most one* $(r \leq 1)$ & 58.38 & 34.81 & 0.0000 \\
At most two $(r \leq 2)$ & 38.00 & 28.59 & 0.0024 \\
At most three $(r \leq 3)$ & 20.46 & 22.30 & 0.0884 \\
At most four $(r \leq 4)$ & 5.26 & 15.89 & 0.8650 \\
\hline
\end{tabular}

Note:* This sign displays, the hypothesis is rejected at $\% 5$ level.

As seen Table 24, Trace and The Max_Eigen statistics are greater than the critical values. They point out two cointegrating equations.

$$
\begin{gathered}
\Delta C A_{t}=-0,30 e c t_{t-1}-0,45 \Delta C A_{t-1}+1,11 \Delta C A_{t-2}+0,25 \Delta A C A_{t-1}-0,46 \Delta A C A_{t-2}+0,21 \Delta D E_{t-1}-0,62 \Delta D E_{t-2} \\
-0,28 \Delta S S P_{t-1}+0,10 \Delta S S P_{t-2}-0,05 \Delta C D S P_{t-1}-0,03 \Delta C D S P_{t-2}
\end{gathered}
$$

Equation 25 shows Cointegration Equation for long run model.

$e c t_{t-1}=A C A_{t-1}+C A_{t-1}-1,01 D E_{t-1}+0,41 S S P_{t-1}+1,23 C D S P_{t-1}-12,20$

Table 25: Vector Error Correction Model

\begin{tabular}{|c|c|c|c|c|}
\hline The Var. & Coeff. & Std. Er. & t-Sta. & Prob. \\
\hline$C(1)$ & $-0,3068$ & 0,0675 & $-4,5454$ & 0,0000 \\
\hline
\end{tabular}

In table 25, $\mathrm{C}(1)$ variable displays Error Correction Term. The coefficient of $\mathrm{C}(1)$ has negative value as well as it is statistically significant. It points out that there is long term causality running from ACA, DE, SSP and CDSP to CA. Furthermore, $\mathrm{R}^{2}$ is $\% 76,6$ which means the model is fitted. 
Table 26: Walt Test

\begin{tabular}{|c|c|c|c|}
\hline Test Statistics & The Variable & Value & Probability \\
\hline Chi-square & DE & 14,21 & 0,0008 \\
\hline Chi-square & ACA & 1,80 & 0,4051 \\
\hline Chi-square & CDSP & 0,70 & 0,7025 \\
\hline Chi-square & SSP & 1,95 & 0,3754 \\
\hline
\end{tabular}

All tests are greater than 0,05 except DE variable. Therefore, it can be stated the existence of the short run causality running from ACA, CDUK and SUK to CA. Moreover, it is possible about existence the short run causality running from DE to CA.

\subsubsection{Turkey}

Cointegration test was applied with lag length of 2 and Model 1.

Table 27: Johansen Cointegration Test (1988) Results for Turkey

\begin{tabular}{|l|ccc|}
\hline Hypothesized Number of CEs & Trace Val. & Critic. Val. & Pro. \\
\hline None* $\left.^{*} r=0\right)$ & 85.56 & 60.06 & 0.0001 \\
At most one* $(r \leq 1)$ & 49.43 & 40.17 & 0.0046 \\
At most two* $(r \leq 2)$ & 25.07 & 24.28 & 0.0397 \\
At most three $(r \leq 3)$ & 4.98 & 12.32 & 0.5700 \\
At most four $(r \leq 4)$ & 1.67 & 4.13 & 0.2303 \\
\hline Hypothesized Number of CEs & Max.Eg.Val. & Critic. Val. & Pro. \\
\hline None* $(r=0)$ & 36.12 & 30.44 & 0.0088 \\
At most one* $(r \leq 1)$ & 24.37 & 24.16 & 0.0469 \\
At most two* $(r \leq 2)$ & 20.08 & 17.80 & 0.0223 \\
At most three $(r \leq 3)$ & 3.31 & 11.22 & 0.7389 \\
At most four $(r \leq 4)$ & 1.67 & 4.13 & 0.2303 \\
\hline
\end{tabular}

Note:* This sign displays the hypothesis is rejected at $\% 5$ level.

The result of all tests in table 27 indicated three cointegrating equation. In addition, the trace value is 25,07 and The Max Eigen statistics is 20,08 . Both of them is more than the $\% 5$ critical value.

The analysis demonstrates that the number of cases of Covid-19 is long-run determinants of financial markets in Turkey.

$$
\begin{gathered}
\Delta C A_{t}=-0,35 e c t_{t-1}-1,12 \Delta C A_{t-1}+0,45 \Delta C A_{t-2}+0,70 \Delta A C A_{t-1}+0,04 \Delta A C A_{t-2}+0,44 \Delta D E_{t-1}-0,31 \Delta D E_{t-2} \\
+0,15 \Delta S T R_{t-1}+0,52 \Delta S T R_{t-2}-0,06 \Delta C D T R_{t-1}-0,053 \Delta C D T R_{t-2}
\end{gathered}
$$

Equation 27 shows Cointegration calculation for long term model.

$e c t_{t-1}=A C A_{t-1}+C A_{t-1}+D E_{t-1}+2,27 S T R_{t-1}-6,13 C D T R_{t-1}$

Table 28: Vector Error Correction Model

\begin{tabular}{|c|c|c|c|c|}
\hline The Var. & Coeff. & Std. Er. & t-Sta. & Prob. \\
\hline$C(1)$ & $-0,3510$ & 0,0583 & $-6,0142$ & 0,0000 \\
\hline
\end{tabular}


As seen table 28, the coefficient of $C(1)$ is negative in as well as it is statically significant. Therefore, the possibility of existence the long run causality running from ACA, DE, SSP and CDSP to CA can be claimed. In addition, $\mathrm{R}^{2}$ of the model is $\% 77,5$. The rate of $R^{2}$ of model is quite adequate.

\section{Table 29: Walt Test}

\begin{tabular}{|c|c|c|c|}
\hline Test Statistics & The Variable & Value & Probability \\
\hline Chi-square & DE & 7,15 & 0,0280 \\
\hline Chi-square & ACA & 5,28 & 0,0713 \\
\hline Chi-square & CDTR & 0,83 & 0,6602 \\
\hline Chi-square & STR & 2,20 & 0,3321 \\
\hline
\end{tabular}

The probability of the Chi-square test is more than 0,05 for ACA, CDTR and STR. Therefore, the existence the short run causality running from ACA, CDUK and SUK to CA cannot ne claimed. Nevertheless, the short run causality is possible when running from DE to CA.

Table 29: The Summarize of Contemporaneous Regression

\begin{tabular}{|c|c|c|c|c|c|c|c|c|c|c|c|c|c|c|c|c|}
\hline & \multicolumn{2}{|c|}{ China } & \multicolumn{2}{|c|}{ France } & \multicolumn{2}{|c|}{ Germany } & \multicolumn{2}{|c|}{ Italy } & \multicolumn{2}{|c|}{ USA } & \multicolumn{2}{|c|}{ UK } & \multicolumn{2}{|c|}{ Spain } & \multicolumn{2}{|c|}{ Turkey } \\
\hline Number & \multicolumn{2}{|c|}{3} & \multicolumn{2}{|c|}{4} & \multicolumn{2}{|c|}{2} & \multicolumn{2}{|c|}{4} & \multicolumn{2}{|c|}{4} & \multicolumn{2}{|c|}{2} & \multicolumn{2}{|c|}{2} & \multicolumn{2}{|c|}{3} \\
\hline & $\begin{array}{l}\text { Lng. } \\
\text { Cas. }\end{array}$ & $\begin{array}{l}\text { Shr. } \\
\text { Cas. }\end{array}$ & $\begin{array}{l}\text { Lng. } \\
\text { Cas. }\end{array}$ & $\begin{array}{l}\text { Shr. } \\
\text { Cas. }\end{array}$ & $\begin{array}{l}\text { Lng. } \\
\text { Cas. }\end{array}$ & $\begin{array}{l}\text { Shr. } \\
\text { Cas. }\end{array}$ & $\begin{array}{l}\text { Lng. } \\
\text { Cas. }\end{array}$ & $\begin{array}{l}\text { Shr. } \\
\text { Cas. }\end{array}$ & $\begin{array}{l}\text { Lng. } \\
\text { Cas. }\end{array}$ & $\begin{array}{l}\text { Shr. } \\
\text { Cas. }\end{array}$ & $\begin{array}{l}\text { Lng. } \\
\text { Cas. }\end{array}$ & $\begin{array}{l}\text { Shr. } \\
\text { Cas. }\end{array}$ & $\begin{array}{l}\text { Lng. } \\
\text { Cas. }\end{array}$ & $\begin{array}{l}\text { Shr. } \\
\text { Cas. }\end{array}$ & $\begin{array}{l}\text { Lng. } \\
\text { Cas. }\end{array}$ & $\begin{array}{l}\text { Shr. } \\
\text { Cas. }\end{array}$ \\
\hline DE & + & + & + & - & + & + & - & - & - & - & + & + & + & + & + & + \\
\hline ACA & + & + & + & - & + & - & - & - & - & - & + & - & + & - & + & - \\
\hline CD & + & - & + & - & + & - & - & - & - & - & + & - & + & - & + & - \\
\hline $\mathbf{S}$ & + & - & + & - & + & - & - & - & - & - & + & - & + & - & + & - \\
\hline
\end{tabular}

Table 29 displays summary result of all Cointregration analysis for eight countries.

\section{CONCLUSION}

The Pandemic first broke out in Wuhan City, China and has become the biggest disaster in the world since The Second World War. It spread very quickly to almost every country in the world in two-three months. From December 2019 to May 12 2020, Covid-19 has caused at least 287,670 people's death and has caused the sickness of more than 4,2 million people.

It paralyzed the health systems of the great number of developed and financially wealthy countries in the world. It caused to cease the works of global trade organizations and supply chains. It has led to instability on micro and macroeconomic conditions of countries. Since the physical areas were dangerous to work cooperatively during pandemic, Covid-19 has ceased the economy. It forced people to stay at home and also live under quarantine conditions.

In this paper, the effects of Covid-19 cases on national economies were analysed. For this purpose, eight selected countries are affected badly from the virus. As an economic variable, daily stock index values and CDS prices of these eight countries were taken. Johansen Cointegration method, long-term relationships among the variables are tested. In addition, the existence of short-term relationships among variables were tested by the VECM model.

According to results, all countries have at least two cointegrations vectors. However, the long-term relationship of Italy and the USA is not statistically significant.

Zeren and Hizirci (2020) has found out the cointregation relationship between Covid-19 cases and Stock indexes of China with Spain. This finding was confirmed in this study, as well. Besides, Zeren and Hizirci (2020) didn't detect any cointregration relationship between Covid-19 cases and Stock indexes of France and Germany. However, in this paper, it can be obviously claimed the existence of the long run causality relationship in France (CAC40) and Germany (DAX). Nevertheless, both studies didn't detect the significant cointegration relationship for Italy.

In addition, there is no short run causality running from ACA, CD, S to CA for France, Germany, Italy, USA, UK and Turkey to CA. In addition, there is the short run causality running from DE to CA for France, Germany, UK, Spain and Turkey to CA. In conclusion, it can be said that there is the short run causality from CA to some variables as significantly. Moreover, there is no short run causality in France, Italy and the USA significantly. 
In conclusion, there is the long term relationship between the cases of total Covid-19 and China, France, Germany, the United Kingdom, Spain, Turkey. But, there is no long term relationship between the case of total Covid-19 and France, Italy and the USA significantly. Furthermore, it can be said that there is short run causality from CA to some variables as significantly. However, there is no short run causality in France, Italy and the USA significantly. Finally, there is no long or short run causality in Italy and the USA.

\section{REFERENCES}

Acar, Y. (2020). Yeni Koronavirüs (Covid-19) Salgını ve Turizm Faaliyetlerine Etkisi. Güncel Turizm Araştırmaları Dergisi, 4(1), 7-21. doi:10.32572/guntad.703410

Ayittey, F. K., Ayittey, M. K., Chiwero, N. B., Kamasah, J. S., \& Dzuvor, C. (2020). Economic impacts of Wuhan 2019-nCoV on China and World. J Med Virol, 92(473-475). doi:10.1002/jmv.25706

Beutels, P., Jia, N., Zhou, Q.-Y., Smith, R., Cao, W.-C., \& Vlas, S. (2009). The economic impact of SARS in Beijing, China. Tropical Medicine and International Health, 14(1), 85-91. doi:10.1111/j.1365-3156.2008.02210.x

Corbet, Shaen and Larkin, Charles James and Lucey, Brian M.,(2020) The Contagion Effects of the COVID-19 Pandemic: Evidence from Gold and Cryptocurrencies, Available at SSRN: https://ssrn.com/abstract=3564443 or http://dx.doi.org/10.2139/ssrn.3564443

Dey, S., Saha, S., \& Akter, R. (2019). Short Run and Long Run Association between Real Exchange Rate and Trade Balance: Empirical Evidence from Bangladesh (Johansen Approach and Vector Error Correction Model). Global Journal of Human-Social Science : E Economics, 19(3).

Fernandes, Nuno, (2020). Economic Effects of Coronavirus Outbreak (COVID-19) on the World Economy. Available at SSRN: https://ssrn.com/abstract=3557504 or doi:10.2139/ssrn.3557504

Gbaiye, O. G., Ogundipe, A., Osabuohien, E., Olugbire, O. O., Adeniran, O. A., Bolaji-Olutunji1, K. A., ... Oluwatomi , A. (2013). Agricultural Exports and Economic Growth in Nigeria (1980-2010). Journal of Economics and Sustainable Developmen, 4, 1-4.

Johansen, S., \& Juselius, K. (1990). Maximum Likelihood Estimation And Inference On Cointegration - With Applications To The Demand For Money. Oxford Bulletin of Economics and Statistics, 52(2), 169-210.

Johansen, S. (1988). Statistical Analysis of Cointegration Vectors. Journal of Economic Dynamics and Control, 12(2-3), 231-254.

McKibbin, W., \& Fernando, R. (2020). The Global Macroeconomic Impacts of COVID-19:Seven Scenarios. The Centre for Applied Macroeconomic Analysis (CAMA), 1-43. doi:10.2139/ssrn.3547729

Ozili, Peterson K and Arun, Thankom,(2020). Spillover of COVID-19: Impact on the Global Economy, Available at SSRN: https://ssrn.com/abstract=3562570 or http://dx.doi.org/10.2139/ssrn.3562570

Pahwa, N. (2018). Impact of Debt on Short Run and Long Run Growth: Empirical Evidence from India. Current Issues in Economics and Finance, 318. doi:10.1007/978-981-10-5810-3_1

Ramelli, Stefano and Wagner, Alexander F., (2020). Feverish Stock Price Reactions to COVID-19. Swiss Finance Institute Research Paper No. $20-12$. Available at SSRN: https://ssrn.com/abstract=3550274 or http://dx.doi.org/10.2139/ssrn.3550274

Zeren, F., \& Atike , H. E. (2020). The Impact of Covid-19 Coronavirus on Stock Markets: Evidence from Selected Countries. Muhase ve Finans Incelemeleri Dergisi, 3(1), 78-84. doi:10.32951/mufider.706159

Zhang, D., Hu, M., \& Ji, Q. (2020). Financial markets under the global pandemic of COVID-19. Finance Research Letters, 101528. doi:10.1016/j.frl.2020.101528

China Data Lab, (2020), "World COVID-19 Daily Cases with Basemap", https://doi.org/10.7910/DVN/L20LOT, Harvard Dataverse, V18, UNF:6:N6nMzAAg+clmLPTNzl+/zQ== [fileUNF] 